\section{Suggested Actions}

- Review your blowdown and makeup water treatment practices; compare them with American Society of Mechanical Engineers (ASME) practices.

- If a continuous-blowdown system is in place, determine the savings an automatic blowdown-control system could attain. Install conductivity monitoring and automatic blowdown control equipment if the proposed project meets your cost-effectiveness criteria.

- Determine the energy savings and cost-effectiveness from using a heat exchanger to recover energy from the blowdown and preheat boiler makeup water. Blowdown heatrecovery systems may be economical for boilers with blowdown rates as low as $500 \mathrm{lb} / \mathrm{hr}$.

\section{Resources}

\section{U.S. Department of Energy-}

DOE's software, the Steam System Assessment Tool and Steam System Scoping Tool, can help you evaluate and identify steam system improvements. In addition, refer to Improving Steam System Performance: A Sourcebook for Industry for more information on steam system efficiency opportunities.

Visit the BestPractices Web site at www.eere.energy.gov/industry/ bestpractices to access these and many other industrial efficiency resources and information on training.

\section{Install an Automatic Blowdown Control System}

\section{Background}

To reduce the levels of suspended and total dissolved solids in a boiler, water is periodically discharged or blown down. High dissolved solids concentrations can lead to foaming and carryover of boiler water into the steam. This could lead to water hammer, which may damage piping, steam traps, or process equipment. Surface blowdown removes dissolved solids that accumulate near the boiler liquid surface and is often a continuous process.

Suspended and dissolved solids can also form sludge. Sludge must be removed because it reduces the heat-transfer capabilities of the boiler, resulting in poor fuelto-steam efficiency and possible pressure vessel damage. Sludge is removed by mud or bottom blowdown.

During the surface blowdown process, a controlled amount of boiler water containing high dissolved solids concentrations is discharged into the sewer. In addition to wasting water and chemicals, the blowdown process wastes heat energy, because the blowndown liquid is at the same temperature as the steam producedapproximately $366^{\circ} \mathrm{F}$ for 150 -pounds-per-square-inch-gauge (psig) saturated steamand blowdown heat recovery systems, if available, are not 100\% efficient. (Waste heat may be recovered through the use of a blowdown heat exchanger or a flash tank in conjunction with a heat recovery system. For more information, see Steam Tip Sheet \#10, Recover Heat from Boiler Blowdown.)

\section{Advantages of Automatic Control Systems}

With manual control of surface blowdown, there is no way to determine the concentration of dissolved solids in the boiler water, nor the optimal blowdown rate. Operators do not know when to blow down the boiler, or for how long. Likewise, using a fixed rate of blowdown does not take into account changes in makeup and feedwater conditions, or variations in steam demand or condensate return.

An automatic blowdown-control system optimizes surface-blowdown rates by regulating the volume of water discharged from the boiler in relation to the concentration of dissolved solids present. Automatic surface-blowdown control systems maintain water chemistry within acceptable limits, while minimizing blowdown and reducing energy losses. Cost savings come from the significant reduction in the consumption, disposal, treatment, and heating of water.

\section{How it Works}

With an automatic blowdown-control system, high- or low-pressure probes are used to measure conductivity. The conductivity probes provide feedback to a blowdown controller that compares the measured conductivity with a set-point value, and then transmits an output signal that drives a modulating blowdown release valve.

Conductivity is a measure of the electrical current carried by positive and negative ions when a voltage is applied across electrodes in a water sample. Conductivity increases when the dissolved ion concentrations increase. 
The measured current is directly proportional to the specific conductivity of the fluid. Total dissolved solids, silica, chloride concentrations, and/or alkalinity contribute to conductivity measurements. These chemical species are reliable indicators of salts and other contaminants in the boiler water.

\section{Applications}

Boilers without a blowdown heat-recovery system and with high blowdown rates offer the greatest energy-savings potential. The optimum blowdown rate is determined by a number of factors, including boiler type, operating pressure, water treatment, and makeup-water quality. Savings also depend upon the quantity of condensate returned to the boiler. With a low percentage of condensate return, more makeup water is required and additional blowdown must occur. Boiler blowdown rates often range from $1 \%$ to $8 \%$ of the feedwater flow rate, but they can be as high as $20 \%$ to maintain silica and alkalinity limits when the makeup water has a high solids content.

\section{Price and Performance Example}

For a 100,000 pound-per-hour (lb/hr) steam boiler, decreasing the required blowdown rate from $8 \%$ to $6 \%$ of the feedwater flow rate will reduce makeup water requirements by approximately 2,300 lb/hr. (See Steam Tip Sheet \#9, Minimize Boiler Blowdown.) Annual energy, water, and chemicals savings due to blowdown rate reductions for a sample system are summarized in the table below. In many cases, these savings can provide a 1- to 3-year simple payback on the investment in an automatic blowdown control system.

Savings Through Installation of Automatic Blowdown-Control System

\begin{tabular}{|c|c|c|c|}
\hline \multirow{2}{*}{$\begin{array}{c}\text { Blowdown Reduction, } \\
\text { lb/hr }\end{array}$} & Fuel & Water and Chemicals & Total \\
\cline { 2 - 4 } & 27,200 & 4,200 & 31,400 \\
\hline 1,000 & 54,400 & 8,400 & 62,800 \\
\hline 2,000 & 108,800 & 16,800 & 125,600 \\
\hline 4,000 & &
\end{tabular}

Note: Based on continuous operation of a 150 -psig, natural gas-fired steam boiler with fuel valued at $\$ 8.00$ per million Btu (\$8.00/MMBtu), a makeup water temperature of $60^{\circ} \mathrm{F}$, and a boiler efficiency of $80 \%$. Water, sewage, and chemical treatment costs are estimated at $\$ 0.004$ per gallon.

Purchasing and installing an automatic blowdown-control system can cost from $\$ 2,500$ to $\$ 6,000$. The complete system consists of a low- or high-pressure conductivity probe, temperature compensation and signal conditioning equipment, and a blowdown-modulating valve. Some systems are designed to monitor both feedwater and blowdown conductivity from multiple boilers. A continuous conductivity recording capability might also be desired. The total cost of the automatic blowdown system is dependent upon the system operating pressure and the design and performance options specified.

\section{Recommended Practices}

The American Society of Mechanical Engineers (ASME) has developed a consensus on operating practices for boiler blowdown. Sections VI and VII of the ASME Boiler and Pressure Vessel Code describe recommended practices. The ASME Boiler and Pressure Vessel Code can be ordered through the ASME Web site at www.asme.org.
BestPractices is part of the Industrial Technologies Program Industries of the Future strategy, which helps the country's most energy-intensive industries improve their competitiveness. BestPractices brings together emerging technologies and best energy-management practices to help companies begin improving energy efficiency, environmental performance, and productivity right now.

BestPractices emphasizes plant systems, where significant efficiency improvements and savings can be achieved. Industry gains easy access to near-term and long-term solutions for improving the performance of motor, steam, compressed air, and process heating systems. In addition, the Industrial Assessment Centers provide comprehensive industrial energy evaluations to small- and medium-size manufacturers.

\section{FOR ADDITIONAL INFORMATION,} PLEASE CONTACT:

EERE Information Center

1-877-EERE-INF

$(1-877-337-3463)$

www.eere.energy.gov

Industrial Technologies Program Energy Efficiency and Renewable Energy U.S. Department of Energy Washington, DC 20585-0121 www.eere.energy.gov/industry

\section{A Strong Energy Portfolio for a Strong AMERICA}

Energy efficiency and clean, renewable energy will mean a stronger economy, a cleaner environment, and greater energy independence for America. Working with a wide array of state, community, industry, and university partners, the U.S. Department of Energy's Office of Energy Efficiency and Renewable Energy invests in a diverse portfolio of energy technologies. 